\title{
El Proceso de lectura en Baltasar de Gertrudis Gómez DE AVELlaneda: LOS PERSONAJES FEMENINOS Y SUS MODOS DE ACTUACIÓN
}

\author{
María Elena Ojea Fernández \\ UNED (Ourense)
}

\section{RESUMEN:}

La recepción inicial del drama bíblico Baltasar de Gertrudis Gómez de Avellaneda no sólo destacaba las virtudes del pueblo judío frente al paganismo de la corte de Babilonia, sino que analizaba el hastío vital del rey tirano. Sin embargo, nuestro proceso de lectura prefiere subrayar la importancia de los personajes femeninos, porque si bien la autora no traiciona las normas de la jerarquía dominante, sí concede una voz diferenciada a la mujer, cuyo modo de actuación se aleja del estereotipo dictado por la cultura oficial.

\section{PALABRAS CLAVE:}

lectura crítica, identidad femenina, estereotipo, voz, foro público.

\begin{abstract}
:
The initial reception of the biblical drama Baltasar by Gertrudis Gómez de Avellaneda is not only focused on defending the values of the Jewish people against the paganism of the Babylonian court, but also on the tedium vitae of the tyrant king. Nevertheless, our reading process wishes to underline the importance of the female characters, because while the author does not betray the rules of the dominant hierarchy, it does grant a differentiated voice to women, whose characterization move away from the stereotype marked out by official culture.
\end{abstract}

\section{KEYWORDS:}

critical reading, feminine identity, stereotype, voice, public forum.

Nuestra intención al elegir como objeto de estudio el drama Baltasar de Gertrudis Gómez de Avellaneda ha sido la de realizar un proceso comprensivo que no valorara exclusivamente el aspecto formal, sino que apuntara al referente. Si como subraya Iser (1987: 215), la obra literaria tiene dos polos: el artístico, creado por el escritor y el estético, llevado a cabo por el lector, nuestra intención será la de seguir a quienes aconsejan que el receptor se abandone en manos del texto para lograr una comprensión más rica (Ricoeur, 1997: 131-133). Si el acceso al pleno sentido de una obra necesita de un análisis «con toda la potencia verbal e imaginativa» (Galván Moreno, 2004: 97), no debe olvidar que lo que una obra lleva en su interior remite a 
la «realidad en cuanto depositaria de las condiciones de inteligibilidad que facilitan la interpretación del texto y al lector en cuanto destinatario de todas las actividades y sensaciones que el texto busca provocar en él» (Garrido, 2004: 121). El enfrentamiento dialéctico de un lector con un texto resulta de gran importancia en la teoría de la recepción literaria (Corriente, 1990: 205), pues nos permite observar con eficacia la conexión existente entre autor, texto y lector (Jauss, 1989: 77).

El éxito arrollador que Baltasar tuvo en su tiempo no alteró los ánimos de la cultura patriarcal, que aplaudió la obra y la incluyó en las corrientes literarias que primaban el idealismo cristiano (Sánchez Llama, 2001: 72). Nuestra mirada inicial ha intentado: «De reconstruir la situación que ha engendrado el texto y la actividad creadora; remontarse del texto, que es un ergon, a la actividad que es una energeia» (Meregalli, 1985: 279). Se ha pretendido una lectura que no aislara el drama del contexto natural de referencia, porque un texto «no se comprende sino en sus contextos $\mathrm{y}$ en sus circunstancias» ${ }^{1}$.

Gertrudis Gómez de Avellaneda subraya en el prólogo a Baltasar que la mujer y el esclavo, seres marginados a quienes el Cristianismo devolvió su dignidad (1973: 38), constituyen lo más relevante de la trama. En el polo opuesto sitúa al déspota, un «alma soberbia, que se imagina sin semejante entre los hombres», pero que nada puede hacer frente a quienes encarnan «la primera revelación de la dignidad humana» (1973: 38). Si nos centramos en la defensa de los más débiles, bien podríamos relacionar esta obra con la novela antiesclavista $S a b$, publicada por Avellaneda en 1841, y creer como Fabián Gutiérrez (1995: 209) que la esclavitud es el sentido último de esta historia. Pero las cosas no son así de sencillas y no podemos hacer una lectura literal de las explicaciones que da un escritor sobre su obra. Debemos esforzarnos por dejar hablar a los hechos antes que por interpretarlos. En realidad, no somos más que «historiadores» cuyo punto de vista gira alrededor de un texto dado (Meregalli, 1985: 279).

Gertrudis Gómez de Avellaneda (1814-1873) nace en Cuba cuando la isla todavía formaba parte del Reino de España. Mujer curiosa e independiente, defendió con vehemencia los derechos de la mujer y fue precursora de la novela en Hispanoamérica. Destacó también en la poesía. Era hija del marino español don Manuel Gómez de Avellaneda y de la cubana doña Francisca de Arteagay Betancourt. Huérfana de padre en la niñez, su madre se casa muy pronto con otro español, don Gaspar Escalada y López de la Peña, por quien Gertrudis no siente simpatía. En 1836 embarca

\footnotetext{
${ }^{1}$ A este respecto, Franco Meregalli distingue entre contextos y circunstancias, reservando el término contexto a los escritos contiguos al texto estudiado y circunstancia a lo que otros llamarían «contexto histórico extraliterario», en «Más sobre la recepción literaria», Anales de Literatura Española, 1985, n. 4, pág. 278.
} 
El proceso de lectura en Baltasar de Gertrudis Gómez de Avellaneda...

con su familia para Europa. Después de una breve estancia en Burdeos, se establecen en La Coruña donde la joven Gertrudis da sus primeros pasos como escritora. Poco tiempo después y en Andalucía, la influencia de Alberto Lista hará que sus poemas se publiquen en periódicos de Cádiz y Sevilla. En esta última ciudad conoce a Ignacio de Cepeda, con quien vive una historia de amor que deja huella en su existencia y al que dedicará su autobiografía. Hacia 1840 se estrena en Sevilla el drama Leoncia. Ya en Madrid sale a la luz su primera colección de poemas y la famosa novela antiesclavista $S a b$. Con la publicación en 1842 de Dos mujeres cosecha críticas negativas a causa de su apoyo al divorcio como remedio a uniones no deseadas. Su relación con el poeta Gabriel García Tassara acaba mal: da a luz una hija que muere a los pocos meses, hecho que incrementa su pesimismo y su soledad. Su vida de penurias no acaba aquí, pues a pesar de los triunfos profesionales (Alfonso Munio se estrena en 1844 con gran éxito y Baltasar lo hará asimismo en 1858), enviuda dos veces; la primera, de Don Pedro Sabater, gobernador civil de Madrid y la segunda, de Don Domingo Verdugo de Massieu, político de gran influencia. En 1860 escribe La Mujer, una serie de artículos con los que pretende demostrar la igualdad intelectual entre hombres y mujeres. Detrás de esa idea quizás se encuentre su fallida candidatura a la Real Academia Española. Tras haber sido agasajada en Cuba como una auténtica gloria nacional, dirige durante varios meses en La Habana una revista titulada Álbum cubano de lo bueno y lo bello (1860). El fallecimiento de su segundo marido acentúa su devoción religiosa. Tras un periplo por Nueva York, Londres y París regresa a España donde fallece en 1873. Si el vacío existencial o el anhelo poético son temas recurrentes en sus poemas, la crítica (muy bien orquestada) de la sociedad patriarcal es un lugar común en sus obras narrativas y aun en su teatro. Como intelectual que pone su talento al servicio de la emancipación de la mujer, fija su atención sobre una parcela de la realidad y dramatiza o narra sobre ella. Hemos elegido el drama Baltasar por ser una obra emblemática que describe el papel secundario que la jerarquía patriarcal reservaba a la mujer y a otros seres subalternos. Avellaneda sabía que el honor femenino estaba a merced de la voluntad del orden dominante, de ahí que su retórica tienda a no levantar susceptibilidades. No olvidemos que nuestra cubana entró en la vida intelectual española como mujer y como indiana, circunstancia que si bien la dotó «de una conciencia crítica respecto de la hegemonía blanca, masculina, metropolitana» (Catelli, 1991: 167), también la volvió prudente acerca del camino a seguir en la cínica España decimonónica. Baltasar gira alrededor de la afrenta padecida por un pueblo (los judíos) a manos de otro (los babilonios) y de la sujeción de la mujer a los dictámenes del varón. Avellaneda da voz al diferente y desautoriza sin ambages los mecanismos opresivos del discurso patriarcal. La autora integra con acierto los modelos literarios del «triunfante romanticismo histórico» (Sánchez 
Llama, 2001: 72) en la Alta Cultura isabelina, que legitimaba el protagonismo femenino sólo si se oponía «a una masculinidad envilecida» (Sánchez Llama, 2001: 82). Nuestro interés se ha centrado en las mujeres del drama porque en la altivez de Elda interpretamos la reivindicación de una protesta íntima contra el racionalismo masculino, y en la sabiduría de Nitocris percibimos la inteligencia de una mujer que destaca muy por encima de sus oponentes masculinos.

\section{La tarea de la interpretación}

Si admitimos que el significado de un texto está en función del intérprete y de su contexto (Domínguez Caparrós, 1993: 130), bien podríamos comenzar con la recepción estética que tuvo Baltasar entre los espectadores de su tiempo. A los rasgos formales que inspiran los valores del neocatolicismo imperante (Sánchez Llama: 2001: 83), hay que añadir el ropaje romántico que cierta crítica percibía en el «taedium vitae» del personaje del rey (Gutiérrez, 1995:205). Ciertamente, y desde la óptica católica, el déspota representa la autoridad pagana identificada exclusivamente con el dominio y la violencia. Nada que ver con el halo de simpatía que envuelve a los seres al margen de la ley en los poemas de Espronceda. Sin embargo, la misma autora subraya en su prólogo que el monarca no era «un personaje de repugnante ociosidad» (Baltasar, 1973: 39) y Menéndez Pelayo lo describe como un ser trágico y solemne, una especie de «ateísta místico» en el sentido que había apuntado Valera (1973: 27). Como la puesta en escena insiste en presentar a un hombre sombrío, con una personalidad inclinada a la reflexión y a la duda, Bravo-Villasante piensa que la fuente de inspiración no se halla en el Sardanápalo de Byron, sino en La vida es sueño de Calderón de la Barca (1973: 22). Baltasar, como también Segismundo, es un hombre fiero, hastiado e iracundo, pero sensible a la belleza femenina. En ambos se opera un cambio de personalidad y de actuación: Segismundo se convierte en el príncipe virtuoso que vence sobre sus instintos y Baltasar acaba reconociendo como único y verdadero al Dios de Israel. Si el acto de lectura constituye una manera de mirar, nosotros nos acercamos al personaje del tirano a partir de la mirada estética que descubrió en él algún rasgo del espíritu de Avellaneda: «esa parte romántica que engloba sus ansias, su sentir y su vida entera» (Gutiérrez, 1995: 208). Incluso Bravo-Villasante veía similitudes entre el discurso del rey de Babilonia y el tono que la escritora hispano-cubana empleaba en su correspondencia (1973: 22). 
El proceso de lectura en Baltasar de Gertrudis Gómez de Avellaneda...

El proceso de lectura de este drama decimonónico nos transporta al triángulo formado por autor, texto y receptor en una historia en la que «se impone el diálogo, la relación interactiva entre el mundo presente del intérprete y el mundo pasado (original) de la obra, tamizado éste por la tradición histórica de sus recepciones» (García Barrientos, 2012: 30)². El mundo de Baltasar parece encerrado entre el Bien y el Mal, dualidad que incorpora el enfrentamiento entre el déspota, al que le resulta imposible hacer el bien y la joven Elda que es incapaz de domar a la bestia. Un caso aparte sería la función de Nitocris, la madre de Baltasar, de la que luego hablaremos. El monarca simboliza tanto el orden y el poder establecido, como el desorden, que aquí se percibe como opuesto al equilibrio y a la transparencia del universo que habita la judía. Si Baltasar encarna el mal absoluto, Elda es un miembro selecto de los israelitas, el pueblo elegido por Dios y cuyos libros sagrados acepta el Cristianismo. La trascendencia de Avellaneda como escritora reside tanto en la calidad y originalidad de su obra como en su actitud personal, pues en el contexto histórico, literario e ideológico que le tocó vivir «abrió una nueva senda al constituirse en sujeto de escritura de género femenino» (Catelli, 1991: 167). Tal vez por ello, cuando nos sumergimos en sus obras, quizá sea correcto preguntarse desde dónde y hacia dónde se aproxima un lector cuando se acerca a un texto (Catelli, 1991: 29). Es conveniente no olvidar que si el proceso comprensivo ha de apuntar al referente (Garrido, 2004: 121), la conveniencia de tender puentes entre el texto y el engranaje histórico-social que lo sustenta se hace necesaria. Hay que señalar que toda estrategia de descodificación ha de tener en cuenta las connotaciones que ofrece el texto. Por lo tanto, nos interesa la recepción decimonónica que tildó a Baltasar de héroe romántico y desde luego, la visión del drama a la luz del feminismo de una autora que reúne en un mismo espacio de marginación social a mujeres y esclavos.

Para los espectadores que acudieron en su época a la representación teatral de Baltasar, el drama empezaba en el acto I. Para quien lee el texto, la obra comienza en el prólogo, donde la escritora confiesa que intentó «encerrar en las estrechas dimensiones de una composición teatral un gran pensamiento filosófico» (1973: 38). Si sostenemos que toda obra de arte resulta de la constitución del texto en la conciencia del lector (Hernández, 2010:105), es evidente que cuando leemos este drama, nuestra comprensión varía en función del horizonte de expectativas: «un texto no es lo que es solamente, sino lo que no es» (Hernández, 2010: 99).

\footnotetext{
${ }^{2}$ Este comentario sigue la línea trazada por Gadamer (1960) para quien la interpretación resulta un proceso fenomenológico e histórico donde autor, texto y lector se mueven e «intervienen sumergidos» en la historia. García Barrientos, José L., Cómo se comenta una obra de teatro. Ensayo de método. México, Paso de Gato, 2012, pág. 30.
} 
La retórica grandilocuente que acompaña la Dedicatoria al Príncipe de Asturias gira alrededor de un Dios «único y universal» que no desoye el arrepentimiento de las almas descreídas. La arbitrariedad de la tiranía logra vencer físicamente a los más débiles, pero no doblegarlos moralmente, pues la fe los libera de cualquier yugo. No obstante, no resulta fácil distinguir el mensaje ideológico de un texto dramático que utiliza los mismos elementos que los dramas románticos más subversivos, pero con una finalidad opuesta: la de «llenar el corazón de piedad cristiana» (Muro, 2010:3 44).

El rey Baltasar, hastiado y desengañado descuida sus obligaciones y su reino. Su encuentro con la esclava Elda lo saca de su letargo, pero ella lo rechaza reprochándole su crueldad y su despotismo. Al saber que está casada con el hebreo Rubén, hijo del último rey de los judíos, no sólo consiente que el pueblo mate al joven, sino que lanza a Elda a la turba de sus soldados. Tal castigo no quedará impune. La esclava enloquece de dolor, pero el reino se desmorona. El monarca agoniza después de reconocer la grandeza de Dios y de obtener el perdón de los judíos. Los persas están ya a las puertas cuando la reina madre quema el palacio y se arroja sobre el cadáver de su hijo.

El estreno apoteósico de Baltasar otorgó a su autora tal prestigio que se permitió no tener rival escénico durante un tiempo. La lectura de Bravo-Villasante describe el drama como «un gran espectáculo» que entusiasmó a personalidades de la talla de Alarcón, Valera y Menéndez Pelayo (1973: 26). Sánchez-Llama distingue en el texto rasgos formales que lo acercarían a las tragedias peninsulares del siglo XVIII, si bien por estética y contenido lo que prevalece es un obra que privilegia el idealismo cristiano y los valores del canon isabelino (2001: 83). La mayor parte de las lecturas de Baltasar han tenido en cuenta la caracterización del rey y en menor medida se han ocupado del resto de personajes, incluidos los personajes femeninos. Fabián Gutiérrez hace una lectura en clave abolicionista (1995: 209), interpretación difícil de aceptar para Miguel Ángel Muro (2010: 353), que considera que este argumento, junto con el del psicoanálisis defendido por Susanne Banusch (1996) resulta indemostrable. Piensa Muro que los esclavos Elda y Rubén son personajes concebidos únicamente para servir de «piedra de toque» al déspota (2010:358), cuyo hastío vital parece ser la razón de ser de una historia que enfrenta el paganismo (identificado con el Mal absoluto) con la fe precursora del Cristianismo (el Bien). Nuestra intención no será observar las consecuencias morales que en clave religiosa pudieran extraerse del drama, sino hacer hincapié en las dos mujeres de la historia, especialmente en Nitocris, personaje poco tratado por la crítica, pero que a nuestro entender es quien mejor contrarresta y define la confusa personalidad del rey de Babilonia. La esclava hebrea tiene entidad propia, aunque Muro la vea como un mero revulsivo a la 
El proceso de lectura en Baltasar de Gertrudis Gómez de Avellaneda...

conciencia del monarca (2010: 360). Cierto es que personifica los ideales del eterno femenino: es joven, bella, virtuosa y fiel, pero también destaca por su valentía, cualidad que comparte con la reina madre. Ambas son mujeres sufridoras: Elda padece el despotismo de Baltasar y la reina intuye con angustia que la sinrazón de su hijo conducirá a la ruina del imperio.

\section{Las protagonistas femeninas y sus modos de actuación}

En una primera lectura, las protagonistas de Baltasar se mueven entre el ansia de libertad y la emancipación personal. Gómez de Avellaneda parece especialmente hábil a la hora de utilizar a sus personajes para difundir sus ideales feministas. Todas sus protagonistas hacen gala de una franqueza y de un atrevimiento que irrita al poder establecido. Elda se rebela porque no quiere ser utilizada como moneda de cambio. Su negativa a cantar y a arrodillarse es una actitud que molesta vivamente a la corte. El rey, atraído por su belleza, quiere proclamarla su favorita, pero la muchacha no cede. Confundido y enojado, el tirano acaba arrojándola a la turba de los soldados. La obra es creíble porque Avellaneda se atiene al contexto patriarcal para hacerlo posible. Era sabido que en el mundo clásico no se toleraba que una mujer hablara en público. Tal abominación sólo era consentida si lo hacía en calidad de víctima o de mártir (Beard, 2018: 22). Elda transgrede el silencio impuesto porque actúa como portavoz de los israelitas, el pueblo elegido por Dios. Y el lector acepta como verdad textual que la autora sitúe en el centro del escenario a una mujer que hace uso de la palabra para defender sus creencias. Fuera de la ficción, todas las que desobedecían las leyes patriarcales eran cruelmente vilipendiadas. El personaje de Elda sorprende por su prudencia, moderación y sabiduría. Es tan consciente de su superioridad moral, que se atreve a recomendar al monarca que se haga amar de su pueblo (Gómez de Avellaneda, Obra selecta, 1990: 256). La atracción que el violento Baltasar siente hacia la judía casi lo humaniza, pero la «salvaje virtud» (Obra selecta, 247) de la muchacha no soporta al tirano que la oprime. No olvidemos que la fe inquebrantable de los israelitas, -como reconoce Bravo-Villasante- (Baltasar, 1973: 24) es uno de los grandes atractivos de la obra. Elda se comporta como se espera de ella: defiende a su pueblo, no se humilla ante un enemigo de la fe y pide ( $\sin$ arrodillarse) la liberación de su esposo. La inteligencia del lector da por buena esta visión porque el personaje representa los ideales del pueblo de Dios. La muchacha no puede inclinarse ante quien no está iluminado por la fe y desprecia a sus semejantes Así las cosas, Avellaneda introduce su idea de la moral femenina en un drama en el que una joven encarna la virtud, el orgullo altivo, la libertad y la independencia. A través de la esclava o gracias a ella se reivindica la dignidad de la mujer. Y todo 
porque la autora fue capaz de «ajustar la forma al fondo de lo que quería expresar» (Rexach, 1973: 254). Nuestro proceso de lectura advierte que para la escritora cubana no hay motivo que sustente la inferioridad secular del sexo femenino. La mujer tiene poder en sí misma y tiene voz propia, por lo que no sólo está al mismo nivel que el varón sino que incluso llega a superarle. La joven hebrea se alza en defensa de su pueblo porque personifica el orgullo y la altivez de quien no se doblega ante una autoridad ilegítima. Hay que subrayar que el discurso masculino -por tradición el único autorizado- está aquí privado de razón y no únicamente desde la perspectiva de la fe. Tanto Baltasar como sus sátrapas viven dominados por las pasiones más abyectas. Si la audacia de Elda sorprende al soberano, su resistencia despierta el alma dormida de un hombre que arde en deseos de hacerla su favorita. La muchacha se niega: « ¡Mi vida es tuya, pero mi alma es mía!», (Obra selecta, 1990: 237) y con sabiduría no exenta de prudencia se atreve a aconsejarle. En un principio, parece que el amor todo lo transforma. Baltasar libera a la cautiva, pero al enterarse de que Rubén no es su hermano sino su marido, reacciona con extrema violencia. La castidad de la mujer inspira en el hombre acciones elevadas, a pesar de que «un hombre, al sentirse engañado, se queda desarmado en lo que concierne a su identidad, pues le afecta en cuanto a individuo y en cuanto varón genérico a la vez», comenta sutilmente Celia Amorós (1985: 209). En fin, por encima de cualquier especulación acerca del sentido de este texto, queremos subrayar que la maestría técnica de Avellaneda dignifica a los seres que pese a su dolorosa situación constituyen «la primera revelación de la dignidad humana y de la pequeñez de las potestades terrestres» ${ }^{3}$. Y esa integridad exige guardar celosamente la libertad personal desafiando incluso las normas del patriarcado. La lectura de esta obra nos retrotrae, en lo que a personajes femeninos se refiere, a Peribáñez y el comendador de Ocaña de Lope de Vega. La joven Elda es inmune a los requiebros del rey, como también Casilda desdeña los del comendador. Si el rey Baltasar impone su voluntad siendo consciente de su poder: «¿No soy yo Baltasar? ¿No soy tu dueño?», (1990: 237), en el drama de Lope, el comendador recuerda a la villana su insignificancia: «Yo soy el comendador / yo soy tu señor» (Peribáñez, 1990: 113). La réplica de la joven esposa: «No tengo / señor mas que a Pedro» (Peribáñez, 1990: 113), confirma que para la cultura dominante la valía de una mujer está a merced de la voluntad masculina, tal y como el rey babilonio había advertido ya a su esclava: «Mi elección te eleva a gloria tanta» (Obra selecta, 1990: 237).

La ideología oficial transmitió la consigna de que el honor del varón residía en la virtud femenina, por lo que el comportamiento de la mujer no sólo era de su incumbencia, sino que debía ser objeto de especial vigilancia. No en vano, la jerarquía

\footnotetext{
${ }^{3}$ Gómez de Avellaneda en la Dedicatoria de Baltasar al Príncipe de Asturias, 1973, págs. 38-39
} 
El proceso de lectura en Baltasar de Gertrudis Gómez de Avellaneda...

«teme y sospecha bien que la docilidad de la casta subordinada enmascara pasiones rebeldes»(Gilbert y Gubar, 1998: 87). Los esposos de Elda y de Casilda, que velan escondidos por el honor de sus mujeres, logran con esta estratagema la prueba definitiva de su fidelidad. La honestidad de una mujer queda entonces probada por el testimonio de su compañero, cuya palabra es la única que acepta la autoridad patriarcal. A este respecto, no debemos pasar por alto el impetuoso reproche de Rubén a su esposa cuando sabe que ha aceptado la oferta de Nitocris: « $i$ Yo los hubiera al punto rechazado!» (Obra selecta, 1990: 209). Si significativo es el consejo que le da: «Solo el deber tu corazón domine.../ ¡Mi fortaleza imita, esposa mía!» (Obra selecta, 1990: 211), no es menos importante el juramento de la esclava antes de partir a palacio: «jJuro conservarme fiel/ a Dios, mi Patria y mi amor!» (Obra selecta, 1990: 212). Pero tales promesas no son suficientes para el varón, que desconfía y pone a prueba la rectitud femenina. Cuando Baltasar permite que la joven regrese con su gente, Rubén la detiene con especial brusquedad: «¿De esposa el sagrado nombre/ aún puedo darte?» (Obra selecta, 1990: 259). La firme reacción de la muchacha desarma los prejuicios patriarcales: «iYo existo!» (pág. 259).

El prestigio de Gómez de Avellaneda durante el período isabelino (1843-1868) fue notable. Si bien se inspira en la moral imperante y en un dominio cultural adscrito al género masculino, su neocatolicismo es menos rígido que el de otros autores coetáneos. Sus escritos, que incluyen (a nuestro juicio) también a Baltasar, son «diametralmente opuestos a las expectativas del discurso patriarcal» (Sánchez-Llama, 2001: 89). La desautorización que sufrió su talento de parte de un varón ilustrado como Valera: «Esta mujer es mucho hombre», (Banusch, 1996: 123), es consecuencia de la tradición secular que despreciaba la capacidad intelectual de las mujeres. Y todo ello sin reparar en que la obra literaria de Avellaneda no atenta directamente contra las reglas de la sociedad hegemónica. Lo que sí hace es subrayar las lagunas del saber dominante, impulsar la identidad femenina más lejos de lo que la tradición reservaba a las mujeres y, por supuesto, no abrazar ni justificar jamás la masculinización intelectual ${ }^{4}$. En el drama que nos ocupa, la autora alaba la superioridad ética de

\footnotetext{
${ }^{4}$ La misoginia de los grandes autores ha sido recientemente estudiada por Anna Caballé en Breve historia de la misoginia, Barcelona, Ariel, 2019. En este libro hay dos citas que hacen referencia a la masculinización de las mujeres intelectuales. La opinión de Rafael Cansino-Asséns y Miguel de Unamuno acerca de Pardo Bazán bien valdría también para Avellaneda: «La obra literaria de una condesa de Pardo Bazán es una cosa seria y sólida como un monumento de esfuerzo masculino» (CansinoAsséns), «Espero tener la ocasión de hablar de masculinismo, que no feminismo de Emilia Pardo Bazán» (Unamuno), pág. 265. La sociedad patriarcal admiraba la pasividad de las mujeres dóciles y discretas, a quienes la autora hispano-cubana parece envidiar: «iCuántas veces envidié la suerte de esas mujeres que no sienten ni piensan, que comen, duermen, vegetan y a las cuales el mundo llama mujeres sensatas!», Caballé, pág. 253.
} 
la mujer, tanto si pertenece al pueblo de Dios (Elda) como si está del lado del paganismo más odioso (Nitocris). La calidad literaria a la hora de presentar a las dos protagonistas es básicamente la misma. No ocurre lo mismo con la calidad dramática, que adquiere mayor relevancia con la actuación de la reina en el último acto (IV). Nitocris está presente en diez de las trece escenas que lo componen. Su caracterización va in crescendo desde el instante en que de forma implacable critica la conducta del rey: «Renuncio a todo poder.../ Que el que empiezas a ejercer / Te aplauda la turba impía / Que el triunfo odioso pregona, / Y al cebarse en su presa / Con su sangre dejó impresa / Negra mancha en tu corona». (Obra selecta, 1990: 266). El tono sarcástico y el acento sordo de Baltasar rehúyen las sabias palabras de una mujer que se retrata en su severa amonestación: «Mas tú -que de despreciar/ cansada tu alma sentías-/ Odiaste lo que debías, / por su grandeza, admirar». (1990: 268). El miedo de la reina a un desenlace funesto se ratifica conforme la acción se encamina hacia el clímax final. La ansiedad la espolea, pero nunca pierde el control: «¿Qué nos anuncia ese cielo/ Con su densa oscuridad?/ ¿Los astros en que leéis/ Nada dicen?» (1990: 275).

La actuación de la madre del rey es interesante porque sale de escena justo cuando Baltasar ordena la muerte de Rubén. Es posible que Avellaneda intuyera que su imagen de valedora de los judíos habría supuesto un desarrollo distinto de la trama (Muro, 2010: 365). De la reina destacamos su interés por la suerte de los esclavos, su indulgencia con Elda; pero lo que más nos atrae es su inteligencia política. Nitocris no ejerce el «poder del impotente» (Amorós, 1985: 108), no presiona de forma oblicua para conseguir sus objetivos, sino que entra de lleno en la vida pública. De ahí la ferocidad de los sátrapas que no toleran su condición de mujer en campo ajeno. La reina es peligrosa porque recuerda al rey sus deberes y porque vigila la suerte de un imperio que se derrumba en manos de un hombre que tiene «envidia del dolor» (Obra selecta, 1990:230), pero que sucumbe ante placeres más terrenales. El talento político de la reina madre subvierte los cimientos de la razón patriarcal, de ahí que la jerarquía censure su presencia en los centros de poder: «Se juzga afrenta / Que rija mi débil mano / De un gran estado las riendas» (1990: 221). Que una mujer pudiera terciar en la lucha política se consideraba antinatural, sobre todo si eran visibles sus dotes de mando. Las esclarecedoras palabras de Pi i Maragall ${ }_{1}$ y Gustave Deville ${ }_{2}$ así lo confirman:

${ }^{1}$ Puede la mujer influir en la marcha política de los pueblos; pero ejerciendo su acción sobre su marido, su padre, sus hermanos, sus hijos si los tiene, inflamándolos en el santo amor de la humanidad y de la patria. Lo repito: en el hogar doméstico, no fuera de él, ha de cumplir la mujer su destino.

(Caballé, 2019: 228) 
El proceso de lectura en Baltasar de Gertrudis Gómez de Avellaneda...

${ }^{2}$ La mujer debe ser mujer, y no traspasar la esfera de los duros e ímprobos destinos reservados al hombre sobre la tierra. Sea enhorabuena poeta, artista; pero nunca sabia. Sea observadora y analice; pero sin tratar por ello de destruir el orden de cosas establecido.

(Caballé, 2019: 239)

Nuestra lectura subraya que la técnica literaria de Avellaneda se sirve del modelo patriarcal para promover cambios con su escritura (Pastor, 2014: 3). Las imágenes femeninas de Elda y de Nitocris, aun siendo representativas de la cultura dominante, se elevan por encima de las de sus oponentes masculinos. Este drama ha sido leído bajo la influencia de Calderón y en relación con el brillo romántico que identificaba a su autora: «Baltasar es la Avellaneda misma, primero víctima de un tedio inexplicable, luego de un amor desgraciado y al final encontrando la paz en la gracia divina» (1973: 28) . Como pensamos que la obra literaria tiene dos polos, el artístico, que se refiere al texto creado por el autor, y el estético, que se relaciona con la concreción llevada a cabo por el lector, sabemos que es la convergencia de ambos la que dota a toda obra literaria de una existencia que no «ha de identificarse ni con la realidad del texto ni con la disposición individual del lector» (Iser, 1987: 215-216). Una obra se pone en marcha a medida que el receptor se vale de las distintas perspectivas que el texto le ofrece. Baltasar se presenta aparentemente como una tragedia oriental en la que cada uno de los personajes se amolda a un rol estereotipado. Se hace hincapié en que la actitud de quien representa la vileza de un mundo decrépito y sin Dios es lo que origina el infausto desenlace. La justicia divina hace su aparición en medio de una atmósfera tétrica que inspira terror religioso ${ }^{6}$ y que advierte de las consecuencias de ignorar la fe verdadera. Pero una vez nos desviamos del tono propagandístico, nuestra atención se encamina hacia las dos mujeres, la esclava y la reina, que recogen la grandeza de espíritu que Avellaneda ambicionaba para su sexo.

En el proceso de lectura de Baltasar no podemos olvidarnos de la importancia de las palabras dichas o intercambiadas entre los personajes, pues el lenguaje solo

\footnotetext{
${ }^{5}$ Bravo-Villasante recoge en su introducción a Baltasar este comentario del crítico Edwin Bucher Wi1liams, 1973, pág. 28. Emilia Bernal compara también al rey con la ilustre cubana en la conferencia leída en La Sorbona el 12 de diciembre de 1923: «Baltasar es ella misma. El atormentado por la rebeldía. Sujeto sin fin en la tierra porque no encuentra, como la autora, nada digno de su alta concepción de la vida». Cuba Contemporánea, 1925, pág. 106.

${ }^{6}$ Bernal subraya que el propósito de este drama es «armonizar la escuela romántica con la clásica» para tratar de implantar en escena un producto que consideraba híbrido. «Una tragedia pseudoclásica y pseudorromántica», que el público aplaudió pero que los autores no imitaron, 1925, pág. 106. Para Bernal, la obra maestra de Avellaneda es Alfonso Munio, un drama nacional que compara con El alcalde de Zalamea... «y sin embargo, a la Avellaneda no se le ha hecho justicia. Acaso sea el prejuicio español contra la literatura femenina», pág. 100.
} 
es creador cuando está al servicio de la ficción (Genette, 1993: 16). Así las cosas, en este drama en verso, Avellaneda resulta más artífice de historias que de versos. Susanne Banusch, que lee la obra en clave psicoanalítica, subraya que vocablos como «casa», «tumba» o «palacio» son símbolos femeninos que nos devuelven al origen porque se identifican con las entrañas maternas (1996: 129). Y, en efecto, cuando los enemigos acechan, la reina madre será el último refugio del monarca caído. Su gesto final incendiando el palacio y arrojándose sobre el cadáver del hijo guarda reminiscencias del Romanticismo, como también lo son los espectros y las tumbas que Elda ve en su delirio o el sacrílego banquete final. En realidad, la obra resulta un espejo que refleja tanto el influjo de los dramas del Siglo de Oro como la desilusión romántica. Baltasar sería entonces un drama histórico de materia bíblica (Mata, 1998: 201) donde el cruel tirano es castigado con la pérdida de su imperio y con la muerte. Pero la ira de Dios, que condena el impío convite del pagano, no se ceba con la madre, cuyo destino lamentarán los líderes hebreos Joaquín y Daniel: «iSeñor, su tormento acorta!», «Mísera madre» (Obra selecta, 1990: 291).

Ninguno de los personajes femeninos acusa en este drama una profunda transformación. Por el contrario, es Baltasar el que abjura de su paganismo inicial en el momento de su muerte. La representación de Elda se nos antoja más convencional, en el sentido que resume esa ejemplaridad femenina que destapa (por contraste) los vicios masculinos. Incluso su entrada en escena en el acto IV nos recuerda a Ofelia en el Hamlet de Shakespeare. En su delirio, la judía se dirige a la madre del rey del mismo modo que Ofelia hablaba a la madre del príncipe. Una y otra han perdido la razón tras un trágico suceso: Ofelia ha perdido a su padre a manos de Hamlet y Elda ha perdido a Rubén por la criminal arbitrariedad del tirano. En ambas obras, la reina madre es una presencia pesarosa.

Los modos de actuación de Elda y de Nitocris muestran una imagen de mujer que parece seguir la norma del patriarcado, pero que de hecho la transgrede. El modo de actuación de la esclava es firme cuando desdeña el espacio opresor que encarna Baltasar. Lo mismo diríamos de la madre, que defraudada primero por la apatía y luego por la sanguinaria sinrazón de su hijo, decide devolverle el sello real y renunciar al ejercicio del poder (Obra selecta, 1990: 266). El juego ficcional de Avellaneda está muy bien orquestado, pues ninguna da la impresión de querer derribar el orden establecido. Elda no puede más que rechazar los ofrecimientos de un impío y la reina se niega a compartir el poder con quien ha manchado su corona con la sangre de un inocente. Las dos mujeres están subordinadas a la jerarquía masculina, pero la firmeza de su carácter es un signo de independencia. Como subrayaron Gilbert y Gubar al hacer hincapié en la relación entre amos y esclavos en el profundo sur de los Estados Unidos: 
El proceso de lectura en Baltasar de Gertrudis Gómez de Avellaneda...

Las mujeres han cultivado tradicionalmente en el patriarcado acentos de asentimiento para obtener la libertad de vivir sus vidas en sus propios términos, aunque solo sea en la intimidad de sus pensamientos.

(1998: 87-88)

Tanto Nitocris como Elda cumplen con celo la ortodoxia patriarcal. Ni una ni otra contradicen la imagen del eterno femenino, pero el acierto de la escritora reside en demostrar que los seres históricamente devaluados esconden una historia propia. Elda rechaza a Baltasar en el estricto cumplimiento de las reglas de su nación, pero con su audacia contribuye al despertar del rey y de sus emociones. Y es precisamente ese modo de actuación el que abre espacios a la labor creativa del lector.

Pocas mujeres, en una situación como la de Elda, amenazada por la venganza de un rey que está dispuesto a destruir a su pueblo han hablado con tal energía hasta este momento en un drama español.

(Gies, 1996: 273)

Si examinamos al personaje de Baltasar en relación a su participación en la acción, como sugiere Gutiérrez, el rey de Babilonia resulta un ser «pasivo» (1995: 208) en clara oposición a otros personajes, sobre todo en claro contraste con los personajes femeninos. La lectura de este estudioso propone un trasfondo de esclavitud militante (pág. 209) que no vemos, o en todo caso, no advertimos la contundencia de una denuncia directa y significativa de marginación social, como sí se percibía en la famosa novela antiesclavista $S a b^{7}$. Si en la Dedicatoria al Príncipe de Asturias la escritora se afana en igualar a la mujer y al esclavo, tal vez sea para enfrentar la idolatría impía del tirano a la pureza ideológica del pueblo precursor del Cristianismo. A nuestro juicio, la intención última de Baltasar genera cierta controversia. Nuestra lectura interpreta un drama de idealismo cristiano donde se dota de vida propia a los personajes femeninos. Otras lecturas han visto en esta obra el tema central de la

\footnotetext{
${ }^{7}$ Bernal considera la narrativa de Avellaneda de inferior calidad a su teatro. No ve a la cubana como una rebelde sino como «una ortodoxa consumada, esclava de prejuicios sociales», 1925, pág. 96. Todo ello no le impide valorar que, aunque «no da más que lo que da su tiempo», sí lo hace con tal fuerza que sobrepasa en concepción a todos los que encarnan su siglo, pág. 97. La fortuna literaria de Avellaneda sufrió altibajos notables. Tras un periodo de esplendor, a partir de 1868 se la asoció a una literatura femenina y virtuosa que supuso su marginación en las letras peninsulares, Sánchez-Llama, 2001, pág. 84.
} 
producción avellanediana: la lucha encarnizada contra la opresión a aquellos seres a quienes se niega el estatus de persona ${ }^{8}$.

Uno de los rasgos significativos de la dramaturgia de nuestra escritora reside en la rebeldía y en el orgullo de sus protagonistas femeninas. Tal vez por ello, es curioso que tras la muerte de Rubén, Elda vague por las estancias reales cumpliendo el típico destino de las damas dolientes; es decir, «el retorno a un mundo providencialista que rechaza una vez más la rebeldía del romanticismo radical» (Gies, 1996: 285). Nuestra lectura entiende que Avellaneda se introduce en el mundo literario (masculino) como sujeto de pleno derecho y ese reto lo mantiene a la hora de concebir el papel que han de desempeñar las mujeres en sus obras. De ahí que sorprenda el oneroso perfil final que reserva a la judía. Sea como fuere, la escritora cubana recurre «con habilidad a la retórica convencional para crear un nuevo estilo o retórica femeninos» (Pastor, 2014: 5). Ese discurso resulta más auténtico en Nitocris, que siempre habla por sí misma, mientras que Elda parece repetir la vieja retórica que la subjetividad femenina se ha visto obligada a interiorizar: «cumplo un deber» $\mathrm{o}$ «las de Dios guardo» (Obra selecta, 1990: 239). Todo ello no impide que la mayoría de las lecturas críticas hayan elogiado de forma unánime la caracterización de la esclava: «Avellaneda conveys the value of human dignity and a compelling example of virtuous conduct» (Albin, Corbin, Marrero, 2017: 16-17). No debemos olvidar que se trata de una pieza religiosa gracias a la cual la autora «renewed the sacred drama from biblical times to include the conflicts that arise when the individual confronts the norms and exigencies of contemporary society» (Albin, Corbin, Marrero, 2017: 16). A nuestro entender, el enaltecimiento de la fe como salvaguardia frente a la tiranía permite a los seres subalternos enfrentarse sin miedo a sus opresores. La escritura de Avellaneda (no sólo los relatos en prosa) se podría leer entonces «como un discurso de doble voz, que contiene una historia "dominante" y otra "silenciada" y que

\footnotetext{
${ }^{8}$ Mary Cruz en su prólogo a Obra selecta de Gertrudis Gómez de Avellaneda. Caracas, Editorial Biblioteca Ayacucho, 1990 compara a la escritora cubana con un don Quijote (femenino) atento a los oprimidos de la sociedad. Insiste en ver en Elda a una mujer sin más estatus social que ser un objeto de culto: virgen venerada, esposa sufridora y objeto de placer, pero nunca persona, pág. xvii del prólogo. Además, la lectura de Cruz identifica la tragedia del pueblo judío con la del pueblo cubano de la época, idea que no entendemos. En relación a la ideología de Avellaneda, recalca que «no era monárquica», aunque se sirvió de amigos poderosos y de la Corte «en bien de su obra», pág. (xvi). Sin embargo, en el lejano 1923, Emilia Bernal había manifestado que en los dramas de nuestra autora, especialmente en Alfonso Munio, se percibía la valentía, el fervor religioso, el sentimiento del honor y la lealtad monárquica como en ningún otro autor. Cuba contemporánea, 1925, pág. 99.
} 
El proceso de lectura en Baltasar de Gertrudis Gómez de Avellaneda...

se la denomina palimpesto» ${ }^{9}$ (Pastor, 2014:4). En este drama o tragedia romántica ${ }^{10}$ Elda y Nitocris están sujetas al sistema patriarcal, pero desarrollan una personalidad que va más allá del mero estereotipo. La frontal oposición de ambas a Baltasar deja al descubierto una identidad femenina que emerge enmascarada entre el fervor religioso de Elda y el deber materno-filial de Nitocris. La rabia y el descontento resuena en las estancias reales tanto como el dolor, personificado en el delirio de la joven hebrea por la muerte de Rubén o en la angustia de la reina madre por el desorden de un imperio, que no sucumbe por su «imprevisión fatal» (Obra selecta, 1990: 290) como perversamente difunden los cortesanos-, sino por la corrupción generalizada. La jerarquía oficial teme el discurso femenino, al que califica de subversivo y caótico, porque cuando una mujer «toma la palabra, su hablar vuelve explícita una voluntad diferente y rebelde respecto al querer del hombre» (Brawer, 1990: 148). Elda y Nitocris consiguen dejar una huella indeleble, una mirada innovadora en el seno del cerrado universo patriarcal, la misma que dejaron las egregias damas que ilustraron las revistas que nuestra autora dirigió tanto en España como en su Cuba natal. En efecto, en Álbum de las damas (1845-1846) y en el Álbum cubano de lo bueno y de lo bello (1860) encontramos una amplia galería de mujeres notables que como la reina ${ }^{11}$ o la esclava hebrea honran con su superioridad ética e intelectual al sexo femenino.

La caracterización de Nitocris se nos antoja lo más interesante de la obra. Sus palabras dicen más de lo que a priori podríamos pensar que están diciendo. La reina es consciente de la debilidad de su hijo y busca en Elda la solución al hastío que lo consume. Aunque está del lado del paganismo politeísta es respetada por los israelitas: «Que es generosa / y de su imperio no abusa, aunque de hacerlo la acusa / toda la corte celosa / Son por su influjo ofendidos / los que ejercerlo ambicionan, / y su virtud no perdonan / los sátrapas corrompidos» (Obra selecta, 1990: 217-18). Generosidad y virtud son palabras que definen a esta mujer a la que Avellaneda presenta como víctima de las intrigas cortesanas. Su modo de actuación la enfrenta mucho más que

\footnotetext{
${ }^{9}$ Pastor continúa la idea de E. Showalter expresada en su libro Literature of their own, Princenton, New Jersey, Princenton University Press, pág. 264.

${ }^{10}$ González Subías denomina tragedias románticas a las obras teatrales de Avellaneda, aunque la variedad métrica, el tono del lenguaje y del ambiente y, sobre todo, la figura del rey babilónico, que recrea en sí mismo «el doloroso sentir del alma romántica» (2005:181) acercarían a Baltasar al drama romántico tradicional. Avellaneda, según González Subías, supera la tragedia neoclásica y el drama romántico para crear algo nuevo con entidad propia: la tragedia romántica.

${ }^{11}$ Avellaneda incluye en estas dos revistas una galería de mujeres célebres al estilo de lo que Pizan y Gourney habían hecho en su tiempo. Christine de Pizan en su libro La ciudad de las damas (1405) y Marie de Gournay en Igualdad de los hombres y las mujeres (1622) sitúan a ambos sexos al mismo nivel intelectual. La lista de mujeres sabias que pueblan estos tratados estaría en sintonía con la intención de Gómez de Avellaneda, especialmente, para el personaje de Nitocris.
} 
a Elda al mundo patriarcal, al que de alguna manera también representa como madre del soberano. Hay que diferenciar a la mujer que insiste en que su hijo cumpla con sus obligaciones y a la reina que lleva las riendas del imperio. Como madre ansía un «modesto retiro» que le permita gozar de una «oscura existencia» (1990: 221). Una vez más la oscuridad y el silencio asociados a la vida femenina. Como reina, surge la consejera que discute la indiferencia y falta de tacto del rey hacia sus súbditos: «Con tal desdén los afliges / y excitas murmuraciones» (1990: 231). Su sagacidad cuando descubre la falsa prosperidad de las satrapías: «Pues corren noticias graves», «Se dan razones / de queja», «Se habla de violentas muertes / también» (Obra selecta, 1990: 276), nos habla de una soberana rigurosa que vela por la salud del Estado. En fin, Baltasar es una obra que retrata cómo la identidad masculina se construye a partir de la opresión a los seres subalternos. Cierto es que Rubén sufre la sinrazón del déspota, pero son las mujeres las que salen peor paradas. Por un lado, la reina madre, cuyo origen patricio no impide que su voz sea cuestionada; y, por otro, la esclava judía, que no sólo ha de soportar los instintos de Baltasar: «iYo soy hombre! ¡Yo deseo!» (1990: 251), sino la incomprensión de su esposo: «iTente! ¿De esposa el sagrado nombre/ aún puedo darte?». Su oportuna réplica: «YYo existo» (1990: 259) es una prueba de que la intransigencia masculina alcanza también al pueblo de Dios. Si los cortesanos envidian el talento de Nitocris y no dudan en desacreditarla, el hebreo Rubén ejerce un control absoluto sobre la castidad de su mujer. La acotación de la escena V del acto III lo presenta como un ser sombrío, que permanece a distancia, pensativo, que no corre al encuentro de Elda cuando a esta le es permitido regresar con los suyos. La moral dominante lo disfraza de esclavo babilonio, para así, oculto entre las sombras, escudriñar la honra de su mujer. El control de la sexualidad femenina nace de la obsesión del varón, cuya identidad se fundamenta en el dominio y en la violencia (Amorós, 1985: 186). Todo ello mientras se atribuye a las mujeres una «indiferenciación en el deseo» (Amorós, 1985: 183) que surge de la falsa creencia acerca del «mito de la insaciabilidad y la capacidad sexual infinita de la mujer» (1985: 186).

\section{Conclusión}

La idea que a primera vista se percibe en Baltasar es que la salvación espiritual está al alcance de todos los que la buscan. La estructura bíblica sirve de base a un discurso teatral que pone de relieve la crueldad de la naturaleza humana cuando en ella reina la bestialidad de un mundo sin gracia. Solo al final, con la conversión del tirano, vuelve a reinar un orden existencial donde Dios y sus criaturas conviven en armonía. En el drama vemos instintos incontrolados, locura, desesperación y muerte, 
El proceso de lectura en Baltasar de Gertrudis Gómez de Avellaneda...

pero, sobre todo, deslealtad del varón hacia la cultura femenina. El disfraz babilónico de Rubén exterioriza la oscuridad de su miedo, del mismo modo que la anarquía feroz de Baltasar refleja su recóndita debilidad y las intrigas de los cortesanos son ejemplos de bajeza moral. Elda y Nitocris sobreviven en un mundo que exige certeza absoluta sobre su fidelidad, pues la mera sospecha será siempre entendida como un desafío a la razón patriarcal. Si lo que distingue a la literatura de calidad reside en su facultad de poder ser sometida a nuevas interpretaciones, como quiere Weisstein (1975: 193), entonces nuestra idea es que en medio de la apoteosis religiosa que castiga a quien contradice la fe verdadera, en medio del hastío existencial y la brutalidad de Baltasar, subyace la asfixiante opresión de un orden simbólico que reprime cualquier movimiento femenino que ose desviarse de la norma. Su intención no es otra que dictar a la mujer sus deberes y recordarle su inferioridad social y política.

Si algo llama la atención, tanto en Baltasar como en toda la obra de Avellaneda, es la presentación consciente de la mujer como ser subordinado a los dictámenes de una autoridad patriarcal de la que depende su reconocimiento social. La autora hispano-cubana no hace crítica social, al menos, no directamente. Las mujeres que aparecen en este drama viven dentro de un sistema que las excluye, no parecen estar «ni dentro ni fuera, no son ni conocidas ni desconocidas» (Moi, 1995: 174). Como defendía Aristóteles, existen seres destinados a mandar y otros a obedecer. Para el Estagirita, la singularidad del esclavo se explica como la de «un ser humano que es poseído por otro ser humano» (García Mercado, 2008: 160). Las mujeres como los esclavos son posesiones de una jerarquía superior y son visibles como «cuerpos de deseo o ultraje e invisibles como sujetos de derechos» (Zúñiga, 2014: 82). Sin embargo, nuestra escritora concede a sus protagonistas acceso al foro público, lugar mítico donde únicamente se asoman quienes son percibidos como sujetos de poder. Y lo hace sin contradecir la norma patriarcal, pues la notoriedad de Elda y de Nitocris viene motivada por el aberrante proceder de Baltasar.

Avellaneda responsabiliza al saber dominante de instigar la frivolidad en la mujer. Observa que la sumisión impuesta a su género es un mal para la sociedad, porque la servidumbre provoca que pierda su libertad y que el Estado no aproveche su talento. Nuestra escritora utilizará el suyo dentro y fuera de la ficción literaria para liberar a su sexo de la inferioridad ontológica impuesta por los hombres instruidos. Sus protagonistas son mujeres que apuestan por hablar en voz alta y no vivir relegadas en la sombra. La cubana fue una personalidad insumisa que defendió sin ambages la libertad de expresión, los derechos de autor y la igualdad entre los sexos. A pesar de que su figura no concordaba con la imagen que proponía la sociedad decimonónica, su espíritu nunca se arredró. Soportó con gran fortaleza el escarnio de sus enemigos y jamás dejó de reclamar mayor presencia femenina en la sociedad. Fue 
«reivindicadora de la mujer, exaltadora de la justicia en todas sus formas y valiente hasta la temeridad cuando de explayar los derechos del corazón y del sentimiento se trataba» (Rexach, 1973: 254). Uno de sus grandes logros lo consiguió en un terreno poco favorable a las mujeres escritoras: la dramaturgia. Su talento aporta al teatro romántico una visión valiente e incluso osada de la realidad, la misma que permite a sus protagonistas resistirse a ser silenciadas. La habilidad de Avellaneda a la hora de difundir sus ideales feministas revela que el discurso masculino (Baltasar y Rubén) está sujeto a numerosas contradicciones. En fin, la creatividad de nuestra autora «devuelve al teatro romántico uno de sus componentes más genuinos: el ser un instrumento revolucionario» (Cantero, 2003: 369). El éxito que Baltasar alcanzó en su tiempo evidencia el talento de la escritora para crear obras de gran teatralidad que funcionaron con eficacia sobre un escenario.

No hemos pretendido interpretar este drama en función de lo que la autora cubana quiso decir, sino en relación a los diversos procesos de lectura que se han hecho de una obra que mezcla el amor y el destino, temas de la corriente romántica muy recurrentes en su producción teatral. Tal vez un texto, como pretende Meregalli, no se comprenda sino en sus contextos y en sus circunstancias (1985: 278), de ahí que no debamos aislar a Baltasar de otras obras de Avellaneda donde es notorio el protagonismo femenino. Sabemos por la Dedicatoria de la importancia otorgada a los seres condenados a un destino común. A nuestro juicio, este drama bíblico ensalza la superioridad ética de la mujer, un ser indispensable para el buen funcionamiento de la sociedad, pero prescindible para determinados aspectos de la misma. La realización estética dibuja una historia principal que tiene que ver con la conducta de Baltasar, además de otra secundaria, consecuencia de la anterior y que involucra a Elda y a Nitocris. A ambas historias se accede a través del lenguaje, porque «el lenguaje es como un tejido» (Catelli, 1991: 34) que reproduce el pensamiento y los modos de actuación de los personajes. Sin interpretar los hechos gratuitamente, antes bien dejándolos hablar, creemos que Avellaneda se sirve de elementos de indiscutible raigambre patriarcal como familia, maternidad, virtud, religión o fe, a los que añade aspectos como audacia y sabiduría, que reivindican el reconocimiento de la capacidad intelectual de su sexo. Todo ello no hace más que confirmar el talante beligerante e innovador de la obra literaria de una escritora que censuró abiertamente el modelo femenino impuesto por las élites ilustradas. Nitocris y Elda no son heroínas, pero sí mujeres notables con las que el lector/espectador puede llega a identificarse. Avellaneda les permite no depender del discurso masculino oficial, aunque sólo sea en la ficción de un escenario. 
El proceso de lectura en Baltasar de Gertrudis Gómez de Avellaneda...

\section{Bibliografía}

Albin, C.; Corbin, M.; Marrero-Fente, R. «Gertrudis the Great: first abolitionist and feminist in the Americas and Spain». HIOL, Hispanic Issues on Line 18, 2017, págs. 1-66

http://conservancy.umn.edu/.../hiol_18_00_albin_corbin_marrero

Acceso 21-II-19

Amorós, C. Hacia una crítica de la razón patriarcal. Barcelona, Anthropos, 1985 Impreso

Banusch, S. «Baltasar de la Avellaneda». Cuadernos Hispanoamericanos, n. 548, 1996, págs. 121-132.

www.cervantesvirtual.com/obra/cuadernos-hispanoamericanos...176

Acceso 16-II-19

Beard, M. Mujeres y poder. Un manifiesto. Barcelona, Crítica, 2018.

Bernal, E. «Gertrudis Gómez de Avellaneda: su vida y su obra» en Cuba contemporánea, 13, 37 (146), La Habana, febrero de 1925, págs. 85-111

http://www.hemerotecadigital.bne.es/pdf.raw?query...name=cuba...2

Acceso 12-IV-19

Brawer, A. «Virginia Woolf: de la ventana y del enigma» en Feminismo y teoría del discurso, Colaizzi, Giulia (ed.), Madrid, Cátedra, 1990, págs. 143152. Impreso

Caballé, A. Breve historia de la misoginia. Barcelona, Ariel, 2019. Impreso

Cantero García, V. «Estudio y análisis de los ideales feministas de Gertrudis Gómez de Avellaneda: tratamiento e importancia de los personajes femeninos en sus dramas» Cuadernos para la Investigación de la Literatura Hispánica, n. 28, 2003, págs. 361-379. http://www.fuesp.com/revistas/pag/cilh.html Acceso 20-VI-19

Catelli, N. El espacio autobiográfico. Barcelona, Lumen, 1991. Impreso

Corriente Cardero, J.M. «Hacia el comentario de texto como estrategia comunicativa: proyección docente». CAUCE. Revista de Filología y Didáctica, n. 13, 1990, págs. 203-218.

http://cvc.cervantes.es/literatura/cauce/pdf/cauce13/cauce 13_11.pdf

Acceso 11-VI-19

Domínguez Caparrós, J. Orígenes del discurso crítico. Teorías antiguas y medievales sobre la interpretación. Madrid, Gredos, 1993. Impreso

Ferrer, T. (ed.). Peribáñez y el comendador de Ocaña. El mejor alcalde, el rey, de Lope de Vega. Barcelona, Planeta, 1990.

http://www.cervantesvirtual.com/nd/ark:/59851/bmc5h878 Acceso10-I-19 
Galván Moreno, L. «El concepto de aplicación en la hermenéutica literaria», Domínguez Caparrós, J (ed.), Signa 13, 2004, págs. 67-101.

García Barrientos, J.L. Cómo se comenta una obra de teatro. Ensayo y método. México, Paso de Gato, 2012. Edición digital corregida y aumentada.

http://www.noteatro.com/wp/wpcontent/uploads/2017/08/GarciaB_

Acceso 10-VII-19

García Mercado, M.A. «El problema de la esclavitud en Aristóteles». Pensamiento, vol. 64, 2008, n. 239, págs. 151-165

http://www.revistas.upcomillas.es/index.php/pensamiento/article/

Acceso 12-XII-18

Garrido Domínguez, A. «El texto literario a la luz de la hermenéutica», Domínguez Caparrós, J. (ed.), Signa 13, 2004, págs. 103-124

Genette, G. Ficción y dicción. Barcelona, Lumen, 1993.

Gies, David T. El teatro en la España del siglo XIX. Cambridge University Press, 1996

http://books.google.es/books?isbn=0521478367 Acceso 14-VI-19

Gilbert, S.M.-Gubar, S. La loca del desván (La escritora y la imaginación literaria del siglo XIX). Madrid, Cátedra, 1998. Impreso

Gómez de Avellaneda, G. Baltasar, Bravo-Villasante, C. (ed.), Madrid, Anaya, 1973.

.Baltasar en Obra selecta de Gertrudis Gómez de Avellaneda, selección, prólogo y bibliografía de Mary Cruz. Caracas, Editorial Biblioteca Ayacucho, 1990.

http://libroschorcha.files.wordpress.com/.../obra-selecta- Acceso 24-II-19

González Subías, J.L. «Gertrudis Gómez de Avellaneda y la tragedia romántica española». En Trueba, V. et al (eds.). Lectora, Heroína, Autora (La mujer en la literatura española del siglo XIX=III Coloquio de la Sociedad de Literatura Española del siglo XIX. Barcelona, Universitat de Barcelona: PPU, 2005, págs. 173-183.

http://www.biblioteca.org.ar/libros7154763.pdf Acceso 10-VII-19

Gutiérrez, F. «La configuración del personaje en Baltasar de Gertrudis Gómez de Avellaneda». Teatro: Revista de estudios teatrales, n. 6-7, 1995, págs. 201-212.

http://ebuah.uah.es/dspace/bitstream/handle/10017/4528 21-IV-19

Hernández, S.M. «El texto y el lector». Fuentes Humanísticas, 2010, n.41, vol. 22, págs. 95-107 www.fuenteshumanisticas.azc.uam.mx/index.php/rfh/ article/view190 Acceso 15-IV-19

Iser, W. «El proceso de lectura: enfoque fenomenológico», en Estética de la recepción, Mayoral, J.A. (ed.), Madrid, Arco Libros, 1987, págs. 215-243 
El proceso de lectura en Baltasar de Gertrudis Gómez de Avellaneda...

Jauss, H.R. «El lector como instancia de una nueva historia de la literatura», en Estética de la recepción, Mayoral, J.A. (ed.), Madrid, Arco Libros, 1987, págs. 59-85

Mata Induráin, C. «Los dramas históricos de Gertrudis Gómez de Avellaneda» en Spang, K (coord.). El drama histórico: Teoría y comentarios. Pamplona, Universidad de Navarra, 1998, págs. 193-213.

www.dadun.unav.edu/handle/10171/21536? Acceso 20-XII-18

Meregalli, F. «Más sobre la recepción literaria» en Anales de Literatura Española, n. 4, 1985, págs. 271-283

http://core.ac.uk/download/pdf/16360990.pdf Acceso 19-II-19

Moi, T. Teoría literaria feminista. Madrid, Cátedra, 1995 Impreso

Muro, M. A. «El subgénero teatral del Romanticismo religioso español: Baltasar de Gertrudis Gómez de Avellaneda» Revista de Literatura, 2010, 144 (72), págs. 341-377 www.revistadeliteratura.revista.csic.es/index/revistadeliteratura/article/

Acceso 18-III-19

Pastor, B. «Un acercamiento teórico a la estrategia retórica femenina de Gertrudis Gómez de Avellaneda» Arbor, vol. 190 (770), 2014, págs. 1-12

http://dx.doi.org/10.3989/arbor.2014.770n6003 Acceso 26-II-19

Rexach, R. «La Avellaneda como escritora romántica». Anales de Literatura Hispanoamericana, n. 2-3 (1973-1974), págs. 241-254

http://revistas.ucm.es/index.php/ALH/article/viewAH17374110241A/25007

Acceso 17-II-19

Ricoeur, P. «La función hermenéutica del distanciamiento» en Hermenéutica, Domínguez Caparrós (ed.), Madrid, Arco Libros, 1997, págs. 115-133 Impreso

Sánchez-Llama, I. «'Baltasar' (1858) de Gertrudis Gómez de Avellaneda (18141873): Análisis de una recepción institucional». Hispanófila, n. 133, 2001, págs. 69-94

http://www.jstor.org/stable/43807166 Acceso 13-III-19

Weisstein, U. Introducción a la literatura comparada. Barcelona, Planeta, 1975.

Zúñiga Elizalde, M. «Las mujeres en los espacios públicos: entre la violencia y la búsqueda de libertad». Región y Sociedad. Número especial 4, 2014, págs. 77-100 www.scielo.org.mx/pdf7/regsoc7v26nspecial4a4.pdf Acceso 16-V-19 